\title{
Investigation of Poly-2-[(4-Pyridilmethylene)-Imino] Phenol's Some Properties: Electrical Conductivity, Antimicrobial Activity and Synthesis of Its Metal Complexes
}

\author{
Haci Okkes Demir ${ }^{1}$, Mehmet Sacak ${ }^{2}$ and Metin Digrak ${ }^{3}$ \\ 1. Department of Chemistry, Kahramanmaras Sutcu Imam University, Kahramanmaras, Turkey \\ 2. Department of Chemistry, Ankara University, Ankara, Turkey \\ 3. Department of Biology, Kahramanmaras Sutcu Imam University, Kahramanmaras, Turkey
}

Received: May 16, 2011 / Accepted: August 19, 2012 / Published: January 25, 2013.

\begin{abstract}
Poly-2-[(4-pyridilmethylene)-imino] phenol-metal complexes were synthesized from the reactions of poly-2-[(4-pyridilmethylene)-imino] phenol with $\mathrm{Cu}(\mathrm{II}), \mathrm{Co}(\mathrm{II}), \mathrm{Zn}(\mathrm{II}), \mathrm{Cd}(\mathrm{II})$ and $\mathrm{Ni}(\mathrm{II})$ ions. The structures of the synthesized compounds were confirmed by FTIR techniques. The thermal stability of the polymer-metal complexes were measured by thermogravimetric analysis under a nitrogen atmosphere and their antimicrobial activites were tested against E. coli, S. aureus, K. pneumoniae, M. smegmatis, P. aeruginosa, B. megaterium and two fungi namely K. fragilis and R. rubra. Also, the electrical conductivities of the poly(2-PIP) have been put forward with this study for the first time.
\end{abstract}

Key words: Oxidative polycondensation, polymer-Schiff base, polymer-chelat complexes, antimicrobial activity and conductivity.

\section{Introduction}

Polyphenols and their Schiff base derivatives have been used in various fields because of their electron structure properties. They possess useful properties such as paramagnetism, semi conductivity, electrochemical cell and resistance to high energy. Because of these properties they were used for photoresistors [1], graphite materials [2], thermostabilizers [3], semiconducting materials [4] and antistatic materials [5]. In addition, Schiff base substitute polyphenols have antimicrobial activity. Antimicrobial activities of polymer metal complexes were studied by Kaya, et al. [6-8]. Thermal properties of polymer metal complexes were studied by

Corresponding author: Haci Okkes Demir, assistant professor, research fields: conjugated polymers, oxidative polycondensation method, synthesis of poly(phenoxy-imine), polyphenols and thermal analysis E-mail address: okkesdemir@hotmail.com.
Khuhawar, et al. [9]. For these reasons, the synthesis of the Schiff base polymer and polymer metal complexes are gaining much interest. In our previous study we investigated the synthesis and characterization of poly(2-PIP) [10].

In the present paper, the synthesis, characterization, antimicrobial and thermal stability studies of poly(2-PIP)-metal complexes were described. Also, electrical conductivity of poly(2-PIP) was investigated.

\section{Experiments}

\subsection{Materials}

$\mathrm{KOH}, \mathrm{H}_{2} \mathrm{SO}_{4}, \mathrm{HCl}$ (37\%), ethyl acetate, ethanol, DMF, THF, DMSO, methanol, acetone, chloroform, toluene, n-hexane and $\mathrm{Cu}(\mathrm{AcO})_{2} \cdot \mathrm{H}_{2} \mathrm{O}$, $\mathrm{Co}(\mathrm{AcO})_{2} \cdot 4 \mathrm{H}_{2} \mathrm{O}, \mathrm{Zn}(\mathrm{AcO})_{2} \cdot 2 \mathrm{H}_{2} \mathrm{O}, \mathrm{Cd}(\mathrm{AcO})_{2} \cdot 2 \mathrm{H}_{2} \mathrm{O}$, $\mathrm{Ni}(\mathrm{AcO})_{2} \cdot 4 \mathrm{H}_{2} \mathrm{O}$ were supplied from Merck (Germany) 

Antimicrobial Activity, and Synthesis of Its Metal Complexes

and were used as received. We have already previously prepared poly-2-[(4-pyridilmethylene)imino] phenol [poly(2-PIP)].

\subsection{Physical Measurements}

Poly(2-PIP) was wholly characterized by elemental analysis, GPC, FT-IR, UV-vis, ${ }^{1} \mathrm{H}-\mathrm{NMR}$ and ${ }^{13} \mathrm{C}-\mathrm{NMR}$ methods as described earlier [10]. The infrared spectra of the metal complexes were measured by a Mattson 1000 FTIR spectrometer. The FTIR spectra were recorded 4,000-550 $\mathrm{cm}^{-1}$. Thermal data of the metal complexes were obtained by using Perkin Elmer Diamond Thermal Analysis. The TG-DTA measurements were made between $20-1,000{ }^{\circ} \mathrm{C}$ (in $\mathrm{N}_{2}$, rate $10{ }^{\circ} \mathrm{C} / \mathrm{min}$ ).

\subsection{Electrical Properties}

Conductivity was measured on a Keithley 2400 Electrometer. The pellet was pressed on a hydraulic press developing up to $1,687.2 \mathrm{~kg} / \mathrm{cm}^{2}$. Iodine doping was carried out by exposure of the pellet to iodine vapor at atmospheric pressure and room temperature in desiccators [11].

\subsection{Synthesis of Poly(2-PIP)-Metal Complexes}

A solution of $\mathrm{M}(\mathrm{AcO})_{2} \cdot \mathrm{xH}_{2} \mathrm{O} \quad\left(\begin{array}{ll}1.5 & \mathrm{mmol}\end{array}\right)$ $\left[\mathrm{Cu}(\mathrm{AcO})_{2} \cdot \mathrm{H}_{2} \mathrm{O}, \mathrm{Co}(\mathrm{AcO})_{2} \cdot 4 \mathrm{H}_{2} \mathrm{O}, \mathrm{Zn}(\mathrm{AcO})_{2} \cdot 2 \mathrm{H}_{2} \mathrm{O}\right.$, $\mathrm{Cd}(\mathrm{AcO})_{2} \cdot 2 \mathrm{H}_{2} \mathrm{O}$ and/or $\left.\mathrm{Ni}(\mathrm{AcO})_{2} \cdot 4 \mathrm{H}_{2} \mathrm{O}\right]$ in methanol $(10 \mathrm{~mL})$ was added to a suspension of poly(2-PIP) $(3.0$ $\mathrm{mmol} / \mathrm{unit})$ in THF $(50 \mathrm{~mL})$. The mixture was stirred and heated at $65{ }^{\circ} \mathrm{C}$ for $6 \mathrm{~h}$. The precipitated complexes were filtered and washed with cold methanol/THF, then dried in the oven (Scheme 1).

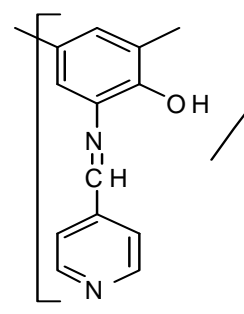

(a)

\subsection{Biological Studies}

The polymer and its metal complexes were evaluated for both their in-vitro antibacterial activity against Escherichia coli ATCC 8739, Staphylococcus aureus Cowan 1, Klebsiella pneumoniae FMC 5, Mycobacterium smegmatis CCM 2067, Pseudomonas aeruginosa ATCC 27853, Bacillus megaterium DSM 32, and their in-vitro antifungal activity against Kluyveromyces fragilis A 230, Rhodotorula rubra by the disc diffusion method [12]. All the bacteria mentioned above were incubated in nutrient broth (NB) (Difco) at $37 \pm 0.1{ }^{\circ} \mathrm{C}$ for $24 \mathrm{~h}$, and the yeasts were incubated in sabouraud dextrose broth (SDB) (Difco) at $25 \pm 0.1{ }^{\circ} \mathrm{C}$ for $48 \mathrm{~h}$. The bacteria and yeasts (prepared as above) were injected into petri dishes $(9$ $\mathrm{cm})$ in the amount of $0.01 \mathrm{~cm}^{3}\left(10^{5} / \mathrm{cm}^{3}\right.$ for the bacteria and $10^{3} / \mathrm{cm}^{3}$ for the fungi), $15 \mathrm{~mL}$ of mueller hinton agar (MHA, Oxoid) and sabouraud dextrose agar (SDA) (sterilized in a flask and cooled to $45-50{ }^{\circ} \mathrm{C}$ ) were homogenously distributed onto the sterilized petri dishes [13]. All the compounds were injected into empty sterilized antibiotic discs having a diameter of 6 mm (Schleicher \& Shüll No. 2668, Germany) in the amount of $25 \mu \mathrm{L}$. The compounds to be tested were dissolved in DMF to a final concentration of 2,000 ppm and soaked in filter paper. Discs injected with complexes were located on the solid agar medium by pressing slightly. After petri dishes so obtained were placed at $4{ }^{\circ} \mathrm{C}$ for $2 \mathrm{~h}$, plates inoculated with fungi were incubated at $25 \pm 0.1{ }^{\circ} \mathrm{C}$ for $24 \mathrm{~h}$. At the end of the period, inhibition zones formed on the food

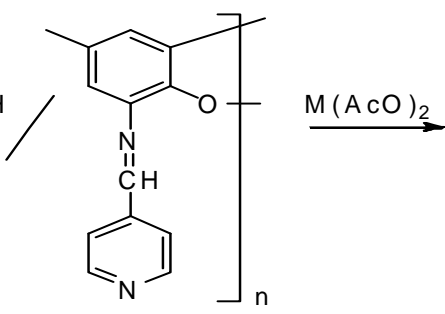

$\mathrm{M}: \mathrm{Cu}(\mathrm{II}), \mathrm{Co}(\mathrm{II}), \mathrm{Zn}(\mathrm{II}), \mathrm{Cd}(\mathrm{II}), \mathrm{Ni}(\mathrm{II})$ $X: \mathrm{H}_{2} \mathrm{O}$ for $\mathrm{Ni}, \mathrm{Co}$

(b)

Scheme 1 The synthesis route of polymer-metal complexes. 


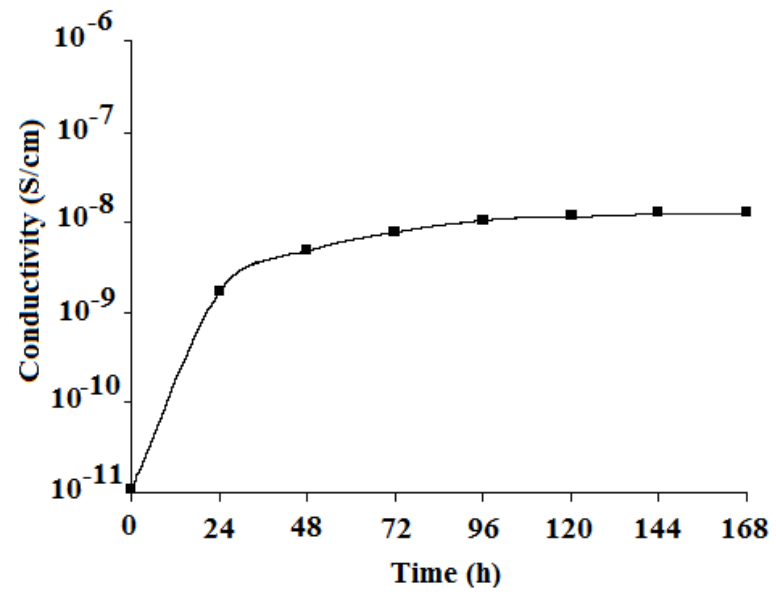

Fig. 1 Electrical conductivity of $\mathbf{I}_{2}$-doped poly(2-PIP) versus doping time at $25^{\circ} \mathrm{C}$.

medium were evaluated is millimeters $[12,13]$. These studies works were performed in triplicate. Gentamicin (Bioanalyse) and Nystatin (Oxoid) were used as standards.

\section{Results and Discussion}

Poly(2-PIP) were prepared and characterized as described earlier [10]. Poly(2-PIP) has conductivities of $10^{-11} \mathrm{~S} / \mathrm{cm}$. When doped with iodine, their conductivities could be increased by about three orders of magnitude (up to $10^{-8} \mathrm{~S} / \mathrm{cm}$ ). Fig. 1 shows the results of poly(2-PIP) doped with iodine at various times at $25{ }^{\circ} \mathrm{C}$. In the doping of poly(2-PIP) with iodine, it was found that the conductivity of poly(2-PIP) first increases greatly with doping time, but then tends to level-off. The maximal (or saturated) conductivity was $1.3 \times 10^{-8} \mathrm{~S} / \mathrm{cm}$ (Fig. 1). The increasing conductivity could indicate that a charge-transfer complex between
poly(2-PIP) and dopant iodine is continuously formed.

The physical data and solubility test of the complexes were given in Table 1. Solubility of the products was investigated in 12 types of solvents in detail. The products were completely insoluble in some of organic solvents such as ethanol, ethyl acetate, methanol, chloroform, hexane, acetone and toluene, and $\mathrm{KOH}$ solutions. The soluble or partly soluble ones were given in Table 1.

In order to better understand the structure of the complexes, the IR spectra of the complexes are given in Fig. 2. The azomethine group $(\mathrm{CH}=\mathrm{N})$ vibration of the monomer and its polymer occurs at $1,643-1,640 \mathrm{~cm}^{-1}$ as a strong band [14]. This band was not observed at the same frequency in the spectra of all the complexes. It shifted to a lower frequency region, indicating the coordination of Schiff base through azomethine nitrogen. Conclusive evidence of the banding is also shown by the observation that new bands in the spectra of the coordination compounds appear at 606-597 and $588-415 \mathrm{~cm}^{-1}$ range assigned to $(\mathrm{M}-\mathrm{O})$ and $(\mathrm{M}-\mathrm{N})$ bands stretching vibrations which are not observed in the spectra of the monomer and polymer. The strong band observed at $3,000 \mathrm{~cm}^{-1}$ for the complexes can be attributed to the $\mathrm{H}_{2} \mathrm{O}$ group vibration [15].

The thermal behaviors of all compounds have been studied using TG and DTA equipments at $\mathrm{N}_{2}$ medium and thermal analyses results and the curves which belong to these compounds are present in Fig. 3 and Table 2 .

The characteristic mass losses related to absorbed

Table 1 The some physical data and solubility results of poly(2-PIP)-metal complexes.

\begin{tabular}{|c|c|c|c|c|c|c|}
\hline \multirow{2}{*}{ Compounds } & \multirow{2}{*}{ m.p. $\left({ }^{\circ} \mathrm{C}\right)$} & \multirow{2}{*}{ Yields (\%) } & \multicolumn{4}{|c|}{ Solubility test } \\
\hline & & & DMF & THF & DMSO & $\mathrm{H}_{2} \mathrm{SO}_{4}$ \\
\hline Poly(2-PIP)-Cu & $>300$ & 95.7 & \pm & - & \pm & + \\
\hline Poly(2-PIP)-Co & $>300$ & 97.1 & \pm & - & \pm & + \\
\hline Poly(2-PIP)-Zn & $>300$ & 95.3 & \pm & - & \pm & + \\
\hline Poly(2-PIP)-Cd & $>300$ & 84.9 & + & - & + & + \\
\hline Poly(2-PIP)-Ni & $>300$ & 97.6 & \pm & - & \pm & + \\
\hline
\end{tabular}

Symbols: $(+)$, soluble; $( \pm)$, partly soluble; (-), insoluble. Abbreviations: m.p., melting points. 


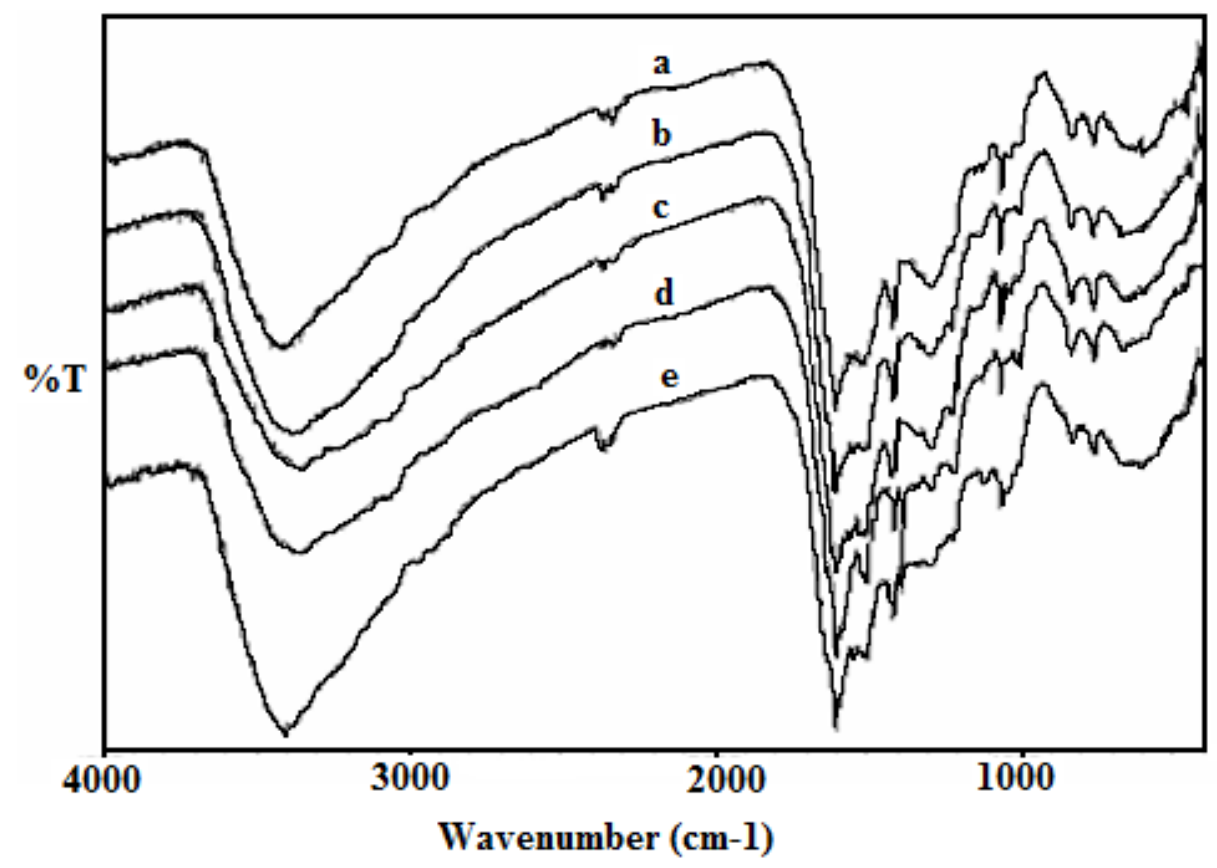

Fig. 2 The IR spectra of poly(2-PIP)-metal complexes (a) $\mathrm{Cu}$, (b) $\mathrm{Co}$, (c) $\mathrm{Zn}$, (d) $\mathrm{Cd}$ and (e) Ni complexes.

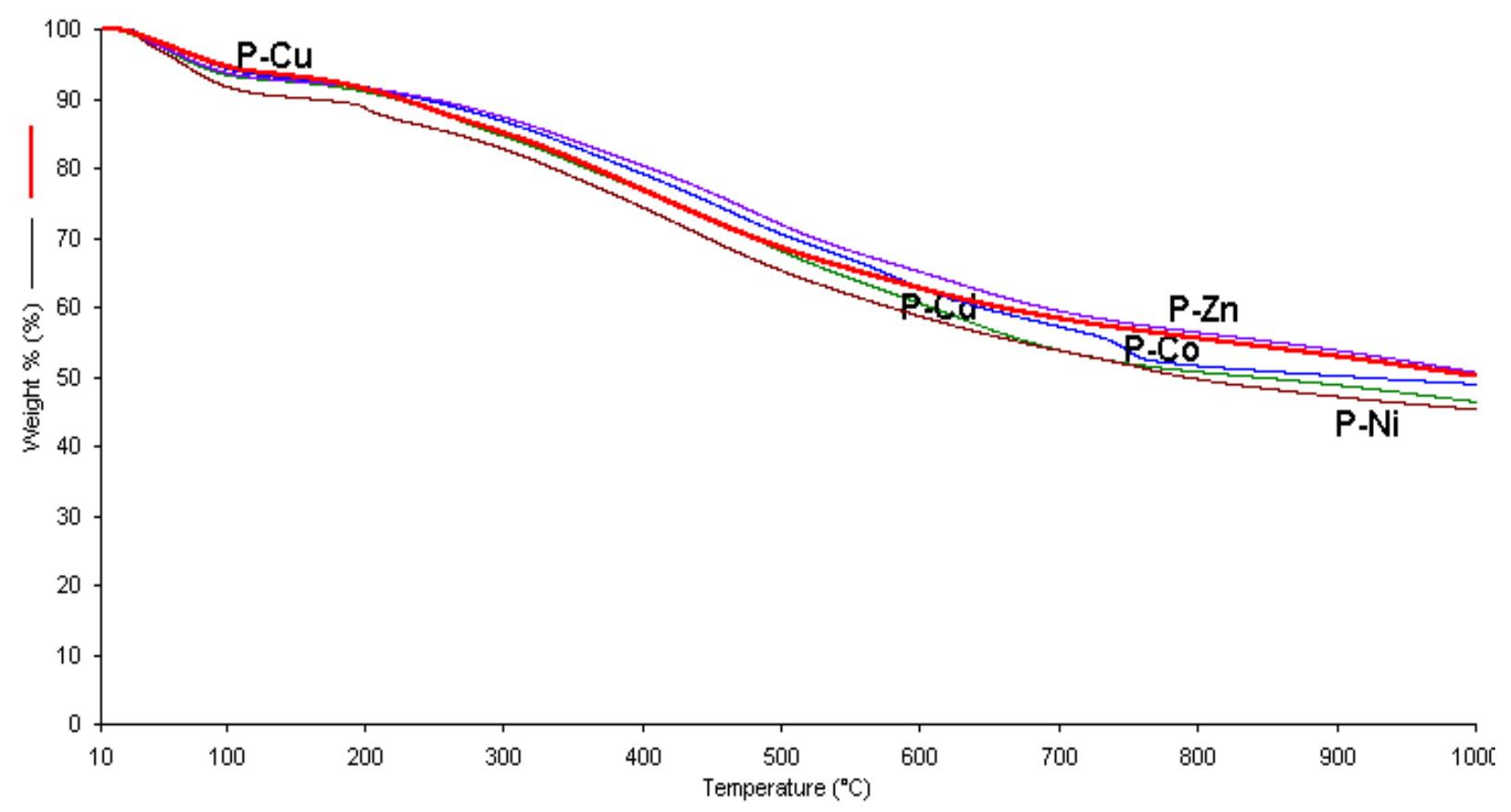

Fig. 3 TGA curves of poly(2-PIP) metal complexes.

Table 2 Thermal values of 2-PIP and poly(2-PIP) metal complexes.

\begin{tabular}{lllcl}
\hline Compounds & Initial $\left({ }^{\circ} \mathrm{C}\right)($ wt loss $)$ & $5 \%\left({ }^{\circ} \mathrm{C}\right)($ wt loss $)$ & $50 \%\left({ }^{\circ} \mathrm{C}\right)($ wt loss $)$ & Char residue $(\%)\left(\right.$ at $\left.1,000{ }^{\circ} \mathrm{C}\right)$ \\
\hline Poly(2-PIP)-Cd & 160 & 263 & 849 & 47.0 \\
Poly(2-PIP)-Co & 173 & 286 & 1,000 & 50.0 \\
Poly(2-PIP)-Cu & 162 & 252 & 1,000 & 50.0 \\
Poly(2-PIP)-Ni & 191 & 264 & 784 & 45.0 \\
Poly(2-PIP)-Zn & 180 & 300 & 1,000 & 50.0 \\
\hline
\end{tabular}


Investigation of Poly-2-[(4-Pyridilmethylene)-Imino] Phenol'S Some Properties: Electrical Conductivity, Antimicrobial Activity, and Synthesis of Its Metal Complexes

Table 3 Antimicrobial activity studies of poly(2-PIP) and its metal complexes [diameter of inhibition zone (mm); concentration $2,000 \mathrm{ppm}, 25 \mu \mathrm{L} / \mathrm{disc}]$.

\begin{tabular}{|c|c|c|c|c|c|c|c|c|}
\hline \multirow{2}{*}{ Compounds } & \multicolumn{6}{|c|}{ Bacteria Inhibition zone, $\mathrm{mm}$} & \multicolumn{2}{|c|}{ Fungi Inhibition zone, $\mathrm{mm}$} \\
\hline & E. coli & i S. aureus & K. pneumoniae & M. smegmatis & P. aeruginosa & B. megaterium & K. fragilis & R. rubra \\
\hline Poly(2-PIP) & 7 & 7 & 8 & 10 & 8 & 0 & 0 & 8 \\
\hline Poly(2-PIP)-Cu & 0 & 0 & 0 & 0 & 0 & 10 & 0 & 7 \\
\hline Poly(2-PIP)-Co & 0 & 0 & 0 & 0 & 0 & 0 & 0 & 22 \\
\hline Poly(2-PIP)-Zn & 0 & 0 & 0 & 0 & 0 & 0 & 0 & 14 \\
\hline Poly(2-PIP)-Cd & 7 & 7 & 7 & 8 & 0 & 0 & 7 & 16 \\
\hline Poly(2-PIP)-Ni & 0 & 8 & 7 & 7 & 0 & 0 & 8 & 14 \\
\hline
\end{tabular}

water molecules were detected between $50-120{ }^{\circ} \mathrm{C}$ for all curves. After this common step all compounds showed a decomposition stage. The 5\% mass losses are at the temperature range of $240-300{ }^{\circ} \mathrm{C}$. The final peaks $1,000{ }^{\circ} \mathrm{C}$ due to occurrence of the metal oxides structure [16]. The poly(2-PIP)-Zn has the highest decomposition temperature for $5 \%$ mass losses.

According to these values, thermal stability of poly(2-PIP) metal-complexes are higher than oligo-N-2-aminopyridinyl salicylaldimine [8], oligo-2-[(pyridine-2-yl-methylene)amino] phenol [17], oligo-4-[(pyridine-3-yl-methylene)amino] phenol [18], oligo-2-[(pyridine-3-yl-methylene)amino] phenol [19].

Fungicidal and bactericidal activities of the Schiff base substitute polymer and its polymer-metal complexes against pathogenic fungi and bacteria are listed in Table 3. The antimicrobial activities of pyridine containing Schiff base substituted oligophenols were examined with E. coli, S. aureus, M. smegmatis, B. megaterium [8, 18], and R. rubra [19] by other groups; however, they did not demonstrate antimicrobial activity toward E. coli, B. megaterium, and $R$. rubra. These researchers did find that poly(2-PIP) exhibited considerable antimicrobial behavior for E. coli, B. megaterium and R. rubra. The results indicate the importance of azomethine polymers or oligomers as new biologically active materials.

\section{Conclusions}

The synthesis of metal complexes of poly-2-[(4-pyridilmethylene)-imino] phenol with $\mathrm{Cu}(\mathrm{II}), \mathrm{Co}(\mathrm{II}), \mathrm{Zn}(\mathrm{II}), \mathrm{Cd}(\mathrm{II})$ and $\mathrm{Ni}(\mathrm{II})$ were achieved.
The new structures were characterized by FT-IR. Also, antimicrobial activities of the metal complexes against E. coli, S. aureus, K. pneumoniae, M. smegmatis, P. aeruginosa and two fungi namely Megaterium and R. rubra were reported. As might be expected the polymer-metal complexes showed thermal stability and graphite material properties. According to electrical conductivity measurement, poly(2-PIP) show a typical semiconductor polymer properties. These properties are important for technological usage.

\section{References}

[1] V.G. Nikolskiy, O.S. Glebova, A.V. Ragimov Positive photoresist, Patent Russia (1979) 4.

[2] E.D. Ionova, S.A. Asaturov, A.V. Ragimov, Composition for impregnation of carbon-graphite manufactures, Patent Russia (1981) 10.

[3] I.A. Anyunene, A.N. Baltushnikas, B.I. Liogony, A.V. Ragimov, Investigation of thermostability of polyamide stabilized by polybetanapthol, in: Abstract of 26th Republic Conference Polymer Materials and Their Investigation, Vulnus, 1981, p. 56.

[4] B.A. Mamedov, Y.A. Vidadi, D.N. Alieva, A.V. Ragimov Paramagnetism and electrical conductivity centre relation in semiconductor oligoresorcinol, Polymer International 43 (2) (1997) 126-128.

[5] A.V. Ragimov, B.A. Mamedov, S.G. Gasanova New efficient dielectric and antistatic materials based on oligoaminophenols. Polymer International 43 (1997) (4) 343-346.

[6] İ. Kaya, H.O. Demir, A.R. Vilayetoğlu, The synthesis and characterisation of planar oligophenol with Schiff base substitute, Synthetics Metals 126 (2/3) (2002) 183-191.

[7] İ. Kaya, A.R. Vilayetoğlu, H. Topak, Synthesis of oligo-ortho-azomethinephenol and its oligomer-metal complexes: characterization and application as anti-microbial agents, Journal of Applied Polymer Science 85 (2002) 2004-2013. 

Antimicrobial Activity, and Synthesis of Its Metal Complexes

[8] I. Kaya, N. Cihangiroglu, Synthesis, characterization and anti-microbial activity

of oligo-N-2-aminopyridinylsalicylaldimine and some oligomer-metal complexes, Journal of Polymer Research 11 (1) (2004) 37-42.

[9] M.Y. Khuhawar, A.H. Channar, S.W. Shah, Syntheses and thermoanalytical studies of some schiff base polymers derived from 5, 5'-methylene bis (2-hydroxyacetophenone) 34 (1) (1998) 133-135.

[10] H.O. Demir, İ. Kaya, M. Saçak, The oxidative polycondensation of 2-[(4-pyridilmethylene)] iminophenol by molecular $\mathrm{O}_{2}$ in alkaline medium: Synthesis and characterization, Polymer Bulletin 60 (2008) $37-48$

[11] F.R. Diaz, J. Moreno, L.H. Tagle, G.A. East, D. Radic Synthesis, characterization and electrical properties of polyimines derived from selenophene, Synthetic Metals 100 (1999) 187-193.

[12] NCCLS (National Committee for Clinical Laboratory Standards). Performance standards for antimicrobial susceptibility testing, The 9th International Supplement., M100-S9, Villanova, PA, 1999, p. 93.

[13] C.H. Collins, P.M. Lyne, J.M. Grange, Microbiological Methods, Sixth Edition, Butterworths \& Co. Ltd., London, 1989, p. 410.

[14] R.M. Silverstein, G.C. Bassler, T.C. Morrill,
Spectrometric identification of organic compounds, 5th Edn., Wiley, New York, 1991, p. 70, 101.

[15] G. Socrates, Infrared Characteristic Group Frequencies, Wiley, New York, 1994, p. 46, 47.

[16] T. Luts, W. Suprun, D. Hofmann, O. Klepel, H. Papp, Epoxidation of olefins catalyzed by novel $\mathrm{Mn}(\mathrm{III})$ and Mo(IV) salen complexes immobilized on mesoporous silica gel: Part 1. Synthesis and characterization of homogeneous and immobilized Mn(III) and Mo(IV) Salen complexes, Journal of Molecular Catalysis A Chemical 261 (1) (2007) 16-23.

[17] İ. Kaya, F. Moral, D. Erdener, Synthesis, characterization and optimum reaction conditions of oligo-2-[(pyridine-2-yl-methylene) amino] phenol, Journal of Polymer Science Part A: Polymer Chemistry 42 (11) (2004) 2717-2724.

[18] İ. Kaya, A. Bilici, M. Saçak, Synthesis, characterization and antimicrobial properties of oligo-4-[pyridine-3-yl-methylene)amino] phenol, Journal of Applied Polymer Science 102 (4) (2006) 3327-3333.

[19] İ. Kaya, D. Emdi, M. Saçak, Synthesis, characterization and antimicrobial properties of oligomer and monomer/oligomer-metal complexes of 2-[(pyridine-3-yl-methylene)amino] phenol, Journal of Inorganic and Organometallic Polymers and Materials 19 (3) (2009) 286-297. 